\title{
Research on the Dynamic Comparative Advantage of Guangxi Cross Border Trade Based on the Silk Road Economic Belt
}

\section{Nanxi GUO}

\author{
Guangxi Technological College of Machinery and Electricity, Nanning, Guangxi, 530007, \\ China
}

Key words: Silk Road Economic Belt; Cross Border Trade Based; Dynamic Comparative Advantage; Guangxi

\begin{abstract}
In recent years, Guangxi's foreign exchanges have become increasingly frequent, cross-border trade has expanded year by year and faster growth, but the total trade volume is too small, the market concentration and product is single, but also facing the ASEAN market increasingly fierce new situation. With the construction of the Silk Road economic belt, for the development of Guangxi has brought new opportunities. Therefore, as the ancient Silk Road origin of Guangxi must give full play to the unique location, policy advantages to build "Maritime Silk Road" cooperation mechanism to expand regional exogenous demand, strengthen foreign trade. This work studies the comparative advantage and dynamic change of Guangxi classified goods by using net export ratio, explicit comparative advantage index and net export dominant comparative advantage index, and obtains the advantages and disadvantages of various kinds of goods. In view of this situation, we should give full play to the comparative advantage of Guangxi's foreign trade and export, avoid the "comparative advantage trap", should improve the quality of maritime transport services, increase the intensity of the development of neighboring markets, increase high-tech product development and other proposals, to enhance the vitality of cross-border trade in Guangxi.
\end{abstract}

\section{Introduction}

In history, the opening of the Silk Road in Shanghai has built a bridge between China and the world. It not only strengthens the connection between China and its neighboring Southeast Asia, but also extends to South Asia and even extends to Europe as a window of China's external relations and with the world Link to a link. With the changing of world pattern, in order to strengthen the external relations and common development of the economy, China put forward the idea of "the Belt and Road", giving the new meaning of the Silk Road on the sea. Guangxi has not only historically connected with the Silk Road on the sea, With the Southeast Asian countries have a direct and indirect link in today's construction of the 21st century Maritime Silk Road is also an indispensable part of the process of combing the development of trade between Guangxi and ASEAN, analysis of its development track on the construction of the 21st century sea Silk Road from the perspective of Guangxi and ASEAN trade has a real significance.

Guangxi cross-border operation of the situation showed a good state, did not show the momentum of deterioration. From the main import and export commodity amount, the export to capital and technology, labor-intensive, import capital and technology, resource-intensive products, the overall export product structure is more reasonable, but from the structural superiority level is still more Big distance. At the same time, a small number of export products export advantages, but the advantages gradually weakened, the amount of exports decreased year by year, the negative impact on economic growth in Guangxi intensified, some commodities in the future may fall into the "comparative advantage trap", and a some of the amount of imports and exports of goods have increased, the comparative advantage in the gradual increase in the economic growth of Guangxi has a certain positive contribution ${ }^{[1-2]}$. 


\section{Analysis on the Comparative Advantage of Guangxi 's Export Commodities[3-5].}

\section{Analysis of net export performance ratio}

Net Export Performance Ratio (NEPR), also known as the trade competitiveness index, is mainly used to measure the difference between the difference between exports and imports in a country or region. Its formula:

$$
N E P R_{p}=\left(E_{x}-M_{y}\right) /\left(E_{x}+M_{y}\right)
$$

In the formula (1), and on behalf of the total value of the export of goods $X$ and the total value of imports, when NEPR $=1$, said the goods $X$ is only the export, the import is zero; when the value is closer to 1, that the goods Export capacity is relatively strong; its value is close to 0 , that the level of import and export of goods is equivalent, foreign trade import and export capacity tends to balance; when the value of the closer to -1, said the goods export capacity is relatively weak; And when NEPR $=-1$, it indicates that the commodity is only imported and the exit is zero. Tab. 1 represents the NEPR index of Guangxi's export commodities:

Tab.1 Estimation of NEPR Index of Foreign Trade Export Commodities in Guangxi

\begin{tabular}{l|l|l|l|l|l}
\hline Years & Electronics & High-tech products & Textile products & Vegetables & Car \\
\hline 2005 & 0.1182 & -0.3513 & 0.9949 & 1 & 0.4497 \\
\hline 2006 & 0.1614 & -0.3091 & 0.9916 & 1 & 0.5708 \\
\hline 2007 & 0.3218 & 0.0585 & 0.9875 & 1 & 0.9878 \\
\hline 2008 & 0.3739 & -0.0064 & 0.9937 & 1 & 0.9641 \\
\hline 2009 & 0.5653 & 0.1977 & 0.9961 & 1 & 0.9626 \\
\hline 2010 & 0.5633 & 0.2915 & 0.9967 & 1 & 0.9981 \\
\hline 2011 & 0.4998 & 0.2462 & 0.9967 & 1 & 0.9977 \\
\hline 2012 & 0.4577 & 0.1775 & 0.9971 & 1 & 0.9955 \\
\hline 2013 & 0.5775 & 0.2309 & 0.9978 & 1 & 0.9979 \\
\hline
\end{tabular}

According to the NEPR index to determine the results: mechanical and electrical products, vegetables, automobiles, textiles and clothing products are four categories of products have comparative advantages, and vegetable products have a complete comparative advantage.

2. Analysis of revealed comparative advantage index

The revealed comparative advantage index is mainly used to predict the results of comparing the competitiveness of a country's or a region's export competitiveness with the world's average export level. The index excludes the influence of the volatility of the country and the fluctuation of the world's total quantity, which can better reflect the relative advantage of the export of a country's industry and the world's average export level. With the consideration of Vietnam as the largest trading partner of Guangxi, Transform the dominant comparative advantage index, with Guangxi five categories of export competitiveness of products and the five categories of Vietnamese exports level competitiveness compared to the five categories. The formula is:

$$
R C A_{x y}=\left(E_{x y} / E_{x}\right) /\left(E_{w y} / E_{w}\right)
$$

In the formula (2), $E_{x y}$ is on behalf of the national $\mathrm{X}$ commodity Y's total export value, $E_{x}$ represents the national X export value of goods, ${ }^{{ }^{w}}$ represents the total value of Vietnam's exports of goods Y, ${ }^{E_{w}}$ represents Vietnam's total exports of goods, Tab.2 is on behalf of Guangxi five categories of goods in Vietnam export the RCA index: 
Tab.2 Estimation of RCA Index of Foreign Trade Export Commodities in Guangxi

\begin{tabular}{l|l|l|l|l|l}
\hline Years & Electronics & High-tech products & Textile products & Vegetables & Car \\
\hline 2005 & 4.6263 & 1.0111 & 3.2976 & 0.2498 & 0.1495 \\
\hline 2006 & 4.7362 & 1.0603 & 3.4081 & 0.2493 & 0.1772 \\
\hline 2007 & 5.3411 & 1.0933 & 3.3646 & 0.1875 & 0.2227 \\
\hline 2008 & 5.9514 & 1.1536 & 3.4184 & 0.1342 & 0.2460 \\
\hline 2009 & 5.6382 & 1.1820 & 3.3041 & 0.1840 & 0.2491 \\
\hline 2010 & 5.6104 & 1.0049 & 3.3026 & 0.2410 & 0.2825 \\
\hline 2011 & 6.2287 & 1.0536 & 3.3605 & 0.2173 & 0.2994 \\
\hline 2013 & 6.3321 & 1.0302 & 3.2750 & 0.1712 & 0.2931 \\
\hline 2014 & 5.1980 & 1.0417 & 3.1905 & 0.1728 & 0.2954 \\
\hline
\end{tabular}

According to the definition of Tab.2 and RCA index, the RCA index of vegetables and cars is less than 1 , and the values fluctuate between 0.1 and 0.3 , which indicates that the comparative advantage is weak and the international competitiveness is poor. Mechanical and electrical products, high-tech products, textile and garment products, three categories of products export performance index values are greater than 1, indicating that these three products in the Vietnamese market are occupying a certain comparative advantage, competitiveness is also greater.

3. Analysis of net export revealed comparative advantage index

The NRCA Index (Net Export Revealed Comparative Advantage Index) reflects the impact of import competitiveness on export competitiveness, mainly by measuring the ratio of one of the export commodities in a country to total exports to the country's difference in the total value of imports in the total imports of all commodities in the country reflects the trade competitive advantage of the industry. The formula is:

$$
N R C A_{x y}=\left(E_{x y} / E\right)-\left(E_{x} / E\right) /\left(E_{y} / E\right)
$$

In the formula (3), the NRCA index is a symmetrical distribution with zero as the product. When $N R C A_{x y}>0$, the commodity $\mathrm{Y}$ has a comparative advantage in the $\mathrm{X}$ country, and the larger the value, the commodity $\mathrm{Y}$ has the stronger comparative advantage; otherwise, $N R C A_{x y}<0$, the commodity $\mathrm{Y}$ In the $\mathrm{X}$ country has a disadvantage, the smaller the value that the comparative advantage of commodity Y more obvious. Tab.3 shows the NRCA index of Guangxi's main export commodities.

Tab.3 Estimation of NRCA Index of Foreign Trade Export Commodities in Guangxi

\begin{tabular}{c|c|c|c|c|c}
\hline Years & Electronics & High-tech products & Textile products & Vegetables & Car \\
\hline 2005 & 0.0002 & -0.1566 & 0.0078 & -0.0013 & -0.0054 \\
\hline 2006 & 0.0014 & -0.1676 & 0.0084 & -0.0015 & -0.0056 \\
\hline 2007 & 0.0021 & -0.1934 & 0.0088 & -0.0016 & -0.0058 \\
\hline 2008 & 0.0035 & -0.0214 & 0.0083 & -0.0022 & -0.0052 \\
\hline 2009 & 0.0048 & -0.0310 & 0.0095 & -0.0023 & -0.0050 \\
\hline 2010 & 0.0001 & -0.0396 & 0.0092 & -0.0026 & -0.0057 \\
\hline 2011 & 0.0015 & -0.0410 & 0.0097 & -0.0028 & -0.0054 \\
\hline 2012 & 0.0009 & -0.0425 & 0.0098 & -0.0031 & -0.0056 \\
\hline 2013 & 0.0012 & -0.0441 & 0.0101 & -0.0033 & -0.0061 \\
\hline 2014 & 0.0012 & -0.0432 & 0.0103 & -0.0030 & -0.0065 \\
\hline
\end{tabular}

According to the definition of the NRCA index and the data in Tab.3, the NRCA indices of the electromechanical products, vegetables and automobiles are negative, indicating that these three types of goods do not have the comparative advantage. Mechanical and electrical products, the comparative disadvantage is weakly expanded in 2014 to -0.043 , with Guangxi actively integrated into the Silk Road economic zone construction, in the future may be more disadvantaged status will improve. 


\section{The influence of the Silk Road economy belt}

\section{Upgrading of foreign cooperation for Guangxi}

The idea of China's "the Belt and Road" get the positive response of around countries, but for the sake of their own interests, countries have different attitudes. According to large data statistical analysis, in the area along "the Belt and Road", the way along the different regions show the heat reflected in different aspects. The hotter regions are Southeast Asia, and they are most looking forward to working with China on infrastructure; followed by Central Asia and South Asia, they are keen to do business with Chinese businesses, while Europe is most concerned about China's overseas investment. Distance from Guangxi recently, the most direct Southeast Asia is the highest degree of concern for the 21st century Maritime Silk Road, the most relevant interests, the most active response to the region. It is clear that in the construction of the Silk Road in the 21st century, Guangxi is adjacent to the Southeast Asian region, which is most concerned about the construction of the Maritime Silk Road in the 21st century. It is undoubtedly a distinctive place for the construction of the Silk Road on the 21st century. The trade between Guangxi and ASEAN has created a more favorable opportunity. The 21st century Maritime Silk Road Construction, will be more effective in promoting trade between Guangxi and ASEAN ${ }^{[6]}$.

2. Upgrading of cross-border trade in Guangxi

The vision of the Maritime Silk Road in the 21st century, with a far-sighted vision, links the major economic sectors such as ASEAN, South Asia, North Africa and Europe through the "the Belt and Road", bringing China to the world stage and making the 21st century Maritime Silk Along the line countries are more closely linked with China, so that Guangxi and ASEAN trade is facing a broader space. The construction of the Silk Road in the 21st century needs to further expand the ASEAN investment market on the basis of expanding the trade of both sides to invest in promoting trade. ASEAN countries welcome foreign investment to help its infrastructure construction, and promote the development of domestic enterprises,there will be more enterprises to go abroad, investment in ASEAN will increase, investment on the one hand to promote the development of local enterprises; the other hand is more conducive to master the local market information and investment environment, which is more conducive to expanding bilateral trade.The expansion of the scale of investment in ASEAN has led to a gradual escalation of bilateral trade in the past to promote trade for investment, and trade development, in turn, to stimulate investment, thus forming a virtuous circle and promoting the development of trade between Guangxi and ASEAN[7].

\section{Summary}

From the above NEPR index, RCA index and NRCA index three indicators of measurement and analysis, the conclusion is: mechanical and electrical products, vegetables, automotive products do not have comparative advantages, and high-tech products and textile and apparel products occupy a certain comparative advantage. Therefore, Guangxi should seize the opportunity of the construction of the Silk Road economic zone, continue to expand economic cooperation with neighboring countries, actively complete industrial upgrading, enhance cross-border trade in high value-added products share, improve the economic level.

\section{References}

[1] Shaorong L. Economic Analysis of the" Belt and Road" Development Strategy[J]. Frontiers, 2016, 5: 006.

[2] Juan S, Jie D, Ping K. An Analysis of the Relationship between Financial Development and Economic Growth in the Western China on the Silk Road Economic Belt[J]. International Journal of Applied, 2016, 4(4)..

[3] Wang J, Huang Z. Analysis and Forecast of Regional Freight Characteristics in the Silk Road Economic Belt[M]//Information Technology and Intelligent Transportation Systems. Springer International Publishing, 2017: 53-63.

[4] Yoshikawa S. China's Maritime Silk Road Initiative and Local Government[J]. Journal of 
Contemporary East Asia Studies, 2016, 5(2): 79-89.

[5] Liang B, Lu R, Li G, et al. Study on the Interactive Relationship Between Cross-Border Trade Development and Construction Land Change-A Case Study of Dongxing City, China[C]//Proceedings of the 20th International Symposium on Advancement of Construction Management and Real Estate. Springer Singapore, 2017: 451-463.

[6] Zhang M, Zuo W, Zheng H. Research on the Coordination Mechanism and Improvement Strategy of the Business Model from China’s Export Cross-border E-commerce-Based on the Theory of Coevolution[J]. 2016.

[7] Li F, Wang Z. To Promote the Sustainable Development of Regional Economies in South Asia by Enhancing Economic Cooperation of the Pan-Red River Basin[J]. World Journal of Social Science Research, 2016, 3(4): 608. 